\title{
VLIV ODPADNÍ KŘEMELINY JAKO VSTUPNÍ SUROVINY NA VLASTNOSTI ANORGANICKÉHO PĚNOVÉHO SKLA
}

\author{
INFLUENCE OF WASTE DIATOMITE AS A RAW MATERIAL ON THE \\ PROPERTIES OF THE INORGANIC FOAM GLASS
}

\author{
Martin Nguyen,, ${ }^{*}$ Martin Sedlačík², Radomír Sokoláŕr ${ }^{1}$, Tomáš Opravil ${ }^{2}$
}

"nguyen.m@fce.vutbr.cz

${ }^{1}$ Vysoké učení technické v Brně, Fakulta stavební, Ústav technologie stavebních hmot a dílců, Veveř́ 331/95, 60200 Brno, Česká republika

${ }^{2}$ Vysoké učení technické v Brně, Fakulta chemická, Ústav chemie materiálů, Purkyňova 464, 61200 Brno, Česká republika

\begin{abstract}
Abstrakt
Tento článek se zabývá procesem výroby anorganického pěnového skla při využití odpadní křemeliny jako vstupní suroviny. Odpadní křemelina byla nejprve podrobena analýze chemického a mineralogického složení. Pěnové sklo bylo vytvořeno pomocí práškové spékací metody lisováním do tablet za př́idavku pěnícího činidla. Po výpalu bylo zkoumány vlastnosti pěnového skla pomocí rentgenové difrakční analýzy, rastrovacího elektronového mikroskopu, stanovení objemové hmotnosti a pevnosti v tlaku. Možnost využití odpadní křemeliny $\mathrm{v}$ surovinových směsích byla zkoumána $\mathrm{v}$ souladu $\mathrm{s}$ vlivem teploty výpalu a výslednými vlastnostmi anorganického pěnového skla.
\end{abstract}

\section{Klíčová slova}

Křemelina, pěnové sklo, průmyslový odpad

\begin{abstract}
This article deals with the manufacturing process of inorganic foam glass with utilization of waste diatomite as a raw material. The waste diatomite was first subjected to an analysis of chemical and mineralogical composition. The foam glass was formed by a powder sintering method by pressing into pellets with the addition of a foaming agent. After firing, the properties of the foam glass were investigated using an X-ray diffraction analysis, scanning electron microscopy, bulk density, and compressive strength. The possibility of utilization of waste diatomite in raw material mixtures was investigated in accordance with the influence of firing temperature and the resulting properties of inorganic foam glass.
\end{abstract}

Key words

Diatomite, foam glass, industrial waste

\section{1 ÚVOD}

Nekalcinovaná odpadní křemelina vzniká při výrobě filtrační křemeliny jako odpad při tř́dění rozplavené křemeliny pomocí odstředivkových trrídičů. Jedná se o materiál obsahující především rozdrcené rozsivkové schránky, jejichž př́tomnost je nežádoucí ve výsledné kalcinační směsi sloužící jako základ pro výrobu filtrační křemeliny. Dále jsou zde obsaženy také jemné částice jílových minerálů, slídy a zbytková voda. Pevné částice $\mathrm{s}$ velikostí pod $10 \mu \mathrm{m}$ tvoří spolu s odpadní vodou majoritní část vedlejších produktů spojených s výrobou filtrační křemeliny [1], [2]. V současné době ovšem tato sekundární surovina, které je na našem území produkováno přibližně 10000 tun ročně, nenachází žádné průmyslové využití.

Cílem tohoto článku je analýza vstupní suroviny - odpadní křemeliny z pohledu chemického a mineralogického složení. Dále výroba anorganického pěnového skla lisováním do tablet za prí́davku pěnícího činidla a výpal pomocí práškové spékací metody. Po výpalu byly stanoveny vlastnosti anorganického pěnového skla jako mineralogické složení, mikrostruktura, objemová hmotnost a pevnost $\mathrm{v}$ tlaku. Rovněž byl sledován vliv teploty výpalu na výsledné vlastnosti anorganického pěnového skla obsahujícího odpadní křemelinu jako vstupní surovinu. 


\section{LITERÁRNÍ PŘEHLED/POPIS SOUČASNÉHO STAVU}

Křemelina je křemičitý sediment složený z opálových schránek rozsivek, což jsou jednobuněčné řasy. Křemelina se vyznačuje vysokou porozitou a z velké části obsahuje oxid křemičitý $\mathrm{SiO}_{2} \mathrm{~V}$ amorfní podobě (více než $70 \%$ ) společně $\mathrm{s}$ dalšími příměsemi, především jílového charakteru [3]. Reakcí běžně využívaných pěnících činidel (glycerol, vodní sklo, hydroxid sodný) s amorfním $\mathrm{SiO}_{2}$ z rozsivkových schránek vznikají hydratované sodné aluminosilikáty a uvolňující se vodní pára způsobuje vznik pórů a celkové napěnění struktury. Výroba křemeliny probíhá nejčastěji povrchovou těžbou z křemelinových ložisek. Surová křemelina zpravidla obsahuje nečistoty závislé na mineralogickém složení daného ložiska a mezi 40 a 60 \% vody. Její zpracování obecně vzato spočívá v drcení, oddělování nečistot, třídění a sušení. Křemelina je nejčastěji využívána pro filtraci materiálů a je její kalcinace probíhá nejčastěji při $650-1250^{\circ} \mathrm{C}$ [1]. V České republice v roce 2018 činila těžba křemeliny přibližně 31 tisíc tun s cenou pohybující se mezi 9 800-16 500 Kč/t. Celkové zásoby křemeliny na území České republiky jsou odhadovány na přibližně 2,3 mil. tun [4]. Celosvětová produkce se pohybuje kolem 2 mld. tun ročně [5].

Nekalcinovaná odpadní křemelina využitá v tomto výzkumném článku vzniká jako druhotná surovina při výrobě filtrační křemeliny jako vedlejší surovina při trrídění rozplavené křemeliny pomocí odstředivkových třídičů. Odpadní křemelina obsahuje především rozdrcené rozsivkové schránky, jejichž přítomnost je nežádoucí pro výrobu filtrační křemeliny. Vzhledem $\mathrm{k}$ tomu, že se jedná o odpad z výroby, jsou zde obsaženy také jemné částice jílových minerálů, slídy a zbytková voda. Při výrobě filtrační křemeliny vznikají odpadní produkty, kterými jsou pevné částice s velikostí pod $10 \mu \mathrm{m}$ a odpadní voda [1], [2]. V současné době tato sekundární surovina, které je v ČR produkováno přibližně 10000 tun ročně, nenachází žádné průmyslové využití.

Pěnové sklo je anorganický tepelně izolační materiál. V důsledku trvalých snah o snižování spotřeby energie a problémů týkajících se požární odolnosti a životnosti organických polymerních tepelně izolačních materiálů, však zájem o tento materiál prudce vzrůstá, a to především díky jeho dlouhé živostnosti a mechanické, teplotní a chemické odolnosti [6], [7]. Celosvětové množství vyrobeného pěnového skla zaznamenává v posledních letech trvalý růst a v roce 2019 dosahovalo více než 1,5 mil. tun s očekávaným nárůstem na téměř 2 mil. tun do roku 2024. Vývoj a modernizace technologie pěnového skla je tedy aktivně se rozvíjející oblastí [8]. V současné době je téměř veškeré průmyslově vyráběné pěnové sklo vyráběno práškovým způsobem za použití redoxních pěnících činidel na bázi uhlíku. Základním materiálem pro jeho výrobu je mleté odpadní sklo, které je následně smícháno s pěnícími přísadami (saze, SiC, glycerol, vodní sklo případně další korekční složky). V peci pak dochází ke slinutí částic skla, a uvolňování plynných produktů reakcí oxidačních reakcí pěnících činidel a utvoření struktury pěnového skla. Hlavní nevýhodou tohoto materiálu je ovšem jeho relativně vysoká cena především ve srovnání s polymerními pěnovými izolacemi [6], [9], [10].

Z hlediska ekonomického, environmentálního a udržitelného rozvoje se v této oblasti jako velmi perspektivní jeví hledání alternativních surovin pro výrobu porézních sklokeramických materiálů. Touto možností se v současné době zabývá celá řada studií, např́íklad z oblasti sekundárních surovin a průmyslových odpadů byly extenzivně zkoumány především možnosti využití elektrárenských popílků [11], [12] a červeného kalu vznikajícího při výrobě hliníku [13]. Z př́rodních silikátových materiálů se vzhledem $\mathrm{k}$ ceně, stabilitě mineralogického složení ložisek a dostupnosti jeví jako nejvhodnější k výrobě pěnových materiálů křemelina. Jedná se o křemičitý sediment složený z opálových schránek rozsivek, vyznačujících se vysokou porozitou a dalších př́měsí, především jílového charakteru [3]. Jeho hlavní výhodou je především vysoký obsah $\mathrm{SiO}_{2}$ v amorfní podobě (i více než $70 \%$ ). Ve studii [14] byla úspěšně ověřena možnost částečné náhrady $(20$ hm. \%) skelné moučky surovou křemelinou při dosažení objemové hmotnosti výsledného produktu $200 \mathrm{~kg} / \mathrm{m}^{3}$ použitím běžně využívaných pěnících činidel (glycerol, vodní sklo). Přípravou izolačního materiálu výhradně za použití křemeliny bez nutnosti prŕídavku skelné moučky se zabývala studie E. A. Yatsenko et al. [15].

\section{METODIKA}

Předmětem výzkumného článku byla př́prava anorganického pěnového skla připraveného práškovou metodou s výzkumem možnosti zpětného využití odpadní křemeliny vznikající při výrobě filtrační křemeliny a roztoku hydroxidu sodného $(\mathrm{NaOH})$. Reakcí $\mathrm{NaOH}$ s kaolinitem a amorfního $\mathrm{SiO}_{2}$ vznikají sodné hydroaluminosilikáty obdobné geopolymerním strukturám (analog zeolitů). Při výpalu pak dochází ke vzniku taveniny a uvolňování strukturně vázané vody. Vodní pára uvolňující se při teplotách vyšších, než je teplota vzniku taveniny pak způsobuje vznik pórů a vlivem snižující se viskozity dochází k jejich zvětšování a napěnění porézní struktury. Nejprve byla provedena analýza mineralogického složení odpadní křemeliny pomocí rentgenové difrakční analýzy, analýza mikrostruktury pomocí rastrovacího elektronového mikroskopu (SEM) a analýza chemického složení pomocí rentgenové fluorescence. Poté byla provedena předúprava odpadní křemeliny, jež spočívala v jejím vysušená v laboratorní sušárně do konstantní hmotnosti, podrcení na čelist'ovém drtiči a následném rozemletí ve vibračním mlýnu. Takto předupravená odpadní křemelina byla smíchána $\mathrm{v}$ poměru $5: 3 \mathrm{~s} 50 \%$ roztokem 
hydroxidu sodného $(\mathrm{NaOH})$. Poté byly směsi uzavřeny do nádoby a ponechány při laboratorní teplotě nebo vloženy do sušárny při $50{ }^{\circ} \mathrm{C}$ nebo $80^{\circ} \mathrm{C}$ po s reakční dobou 60 minut.

Z těchto směsí byly poté lisovány tablety s hmotností $20 \mathrm{~g}$ a průměru $40 \mathrm{~mm}$ pomocí hydraulického lisu tlakem $2 \mathrm{MPa}$ po dobu $30 \mathrm{~s}$, což je běžný postup při výzkumu a vývoji pěnového skla bez nutnosti použití teplotně odolných kovových forem. Vylisované tablety byly poté vypáleny na tři různé vypalovací teploty $800{ }^{\circ} \mathrm{C}, 850{ }^{\circ} \mathrm{C}$ a $900{ }^{\circ} \mathrm{C}$ s teplotním nárůstem $5{ }^{\circ} \mathrm{C} /$ min a teplotní výdrží 30 min při maximální teplotě. Na vypálených tabletách bylo poté stanoveno mineralogické složení pomocí rentgenové difrakční analýzy, mikrostruktura byla stanovena pomocí rastrovacího elektronového mikroskopu, objemová hmotnost byla stanovena postupem dle ČSN EN 12390-7 na vzorcích seřezaných do pravidelného tvaru a pevnost v tlaku dle ČSN EN 993-5 pomocí laboratorního hydraulického lisu Instron.

\section{VÝSLEDKY}

Tab. 1 Chemické složení vstupní složení - odpadní křemeliny.

\begin{tabular}{ccccccccccc}
\hline $\mathbf{S i O}_{\mathbf{2}}$ & $\mathbf{A l}_{\mathbf{2}} \mathbf{O}_{\mathbf{3}}$ & $\mathbf{F e}_{\mathbf{2}} \mathbf{O}_{\mathbf{3}}$ & $\mathbf{T i O}_{\mathbf{2}}$ & $\mathbf{C a O}$ & $\mathbf{K}_{\mathbf{2}} \mathbf{O}$ & $\mathbf{C u O}$ & $\mathbf{B a O}$ & $\mathbf{P}_{\mathbf{2}} \mathbf{O}_{\mathbf{5}}$ & $\mathbf{S O}_{\mathbf{3}}$ & $\mathbf{\mathbf { Z }} \check{\mathbf{Z}}^{*}$ \\
\hline 63,90 & 18,06 & 3,29 & 0,81 & 0,70 & 0,33 & 0,23 & 0,08 & 0,07 & 0,05 & 10,71 \\
\hline${ }^{*}$ Ztráta žíháním & & & & & & & & &
\end{tabular}

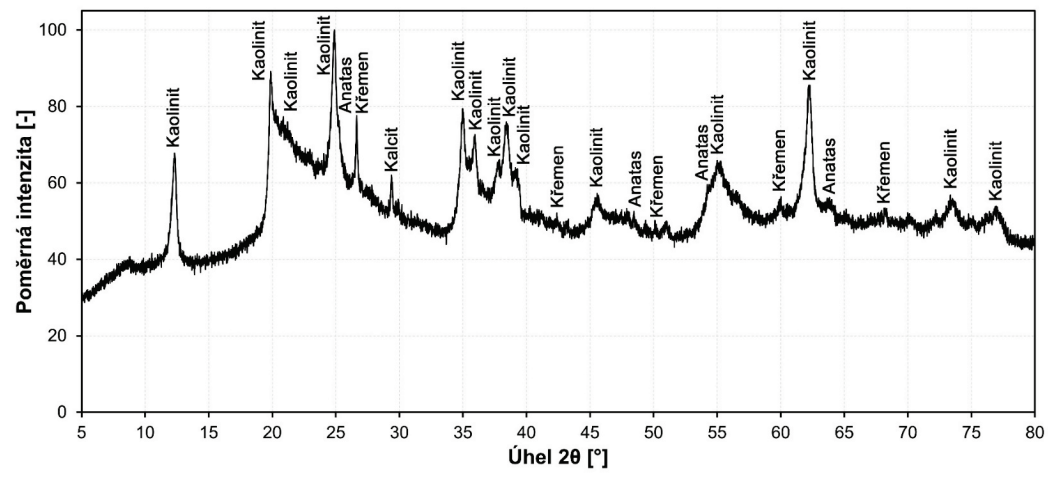

Obr. 1 Mineralogické složení odpadní křemeliny.

Tab. 2 Kvantitativní zastoupení minerálů a amorfní fáze v odpadní křemelině.

\begin{tabular}{cc}
\hline Minerál & Obsah [\%] \\
\hline Kaolinit $\left(\mathrm{SiO}_{2} \cdot \mathbf{A l}_{2} \mathbf{O}_{3} \cdot \mathbf{2} \mathbf{H}_{2} \mathrm{O}\right)$ & 59,85 \\
$\mathrm{Křemen}\left(\mathrm{SiO}_{2}\right)$ & 0,25 \\
Anatas $\left(\mathrm{TiO}_{2}\right)$ & 0,49 \\
Kalcit $\left(\mathrm{CaCO}_{3}\right)$ & 0,25 \\
Amorfní fáze $\left(\mathrm{SiO}_{2}\right)$ & 39,16 \\
\hline
\end{tabular}

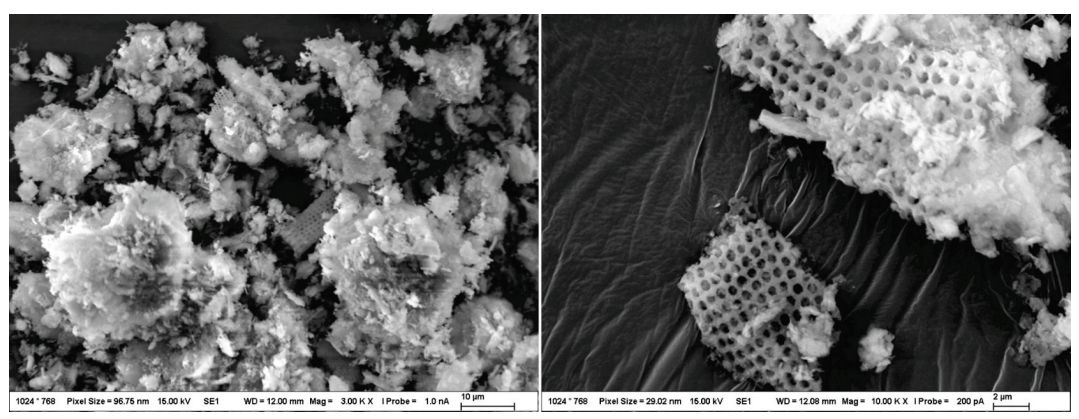

Obr. 2 Fotografie odpadní křemeliny ze SEM se schránkami rozsivek (zvětšení vlevo 3 000×; vpravo 10 000×). 


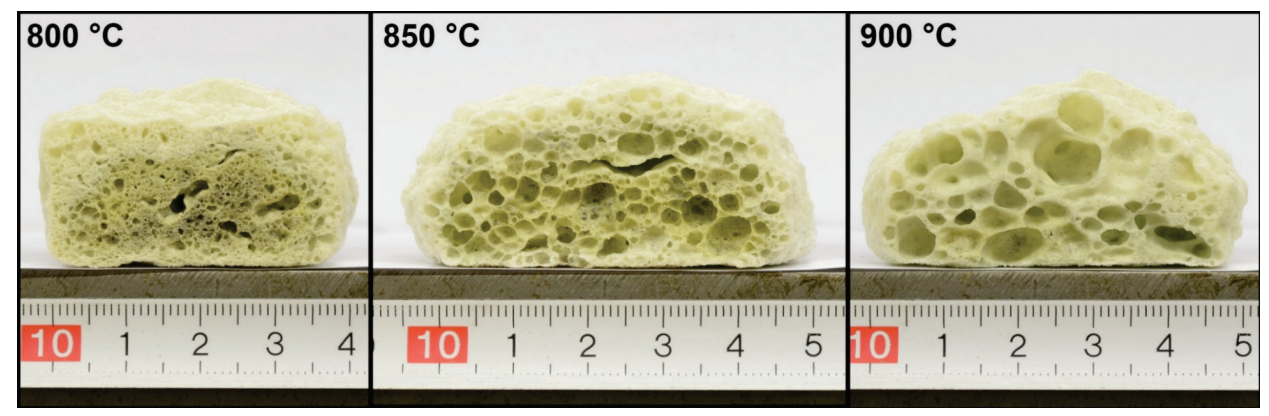

Obr. 3 Fotografie pěnových skel po výpalu na tři různé teploty.

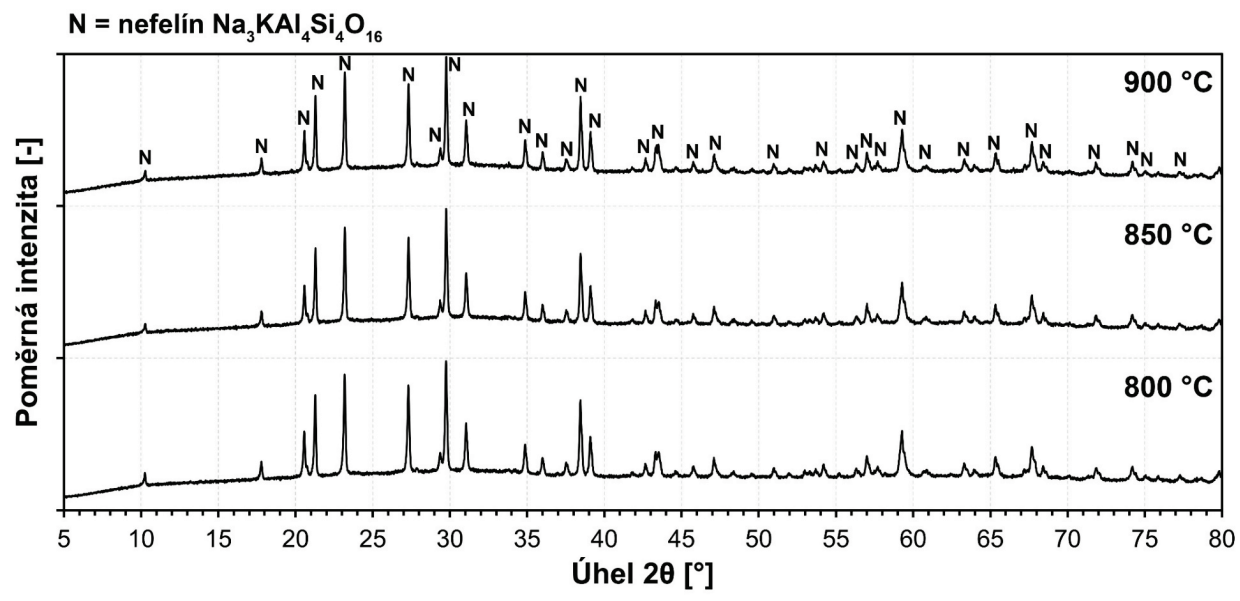

Obr. 4 Rentgenová difrakční analýza pěnového skla vypáleného na tři různé teploty.

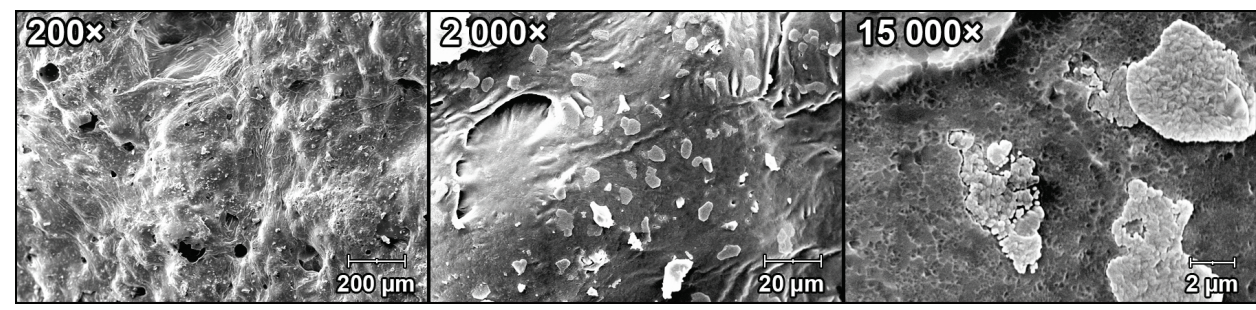

Obr. 5 Mikrofotografie vnějšího povrchu pěnového skla ze SEM.

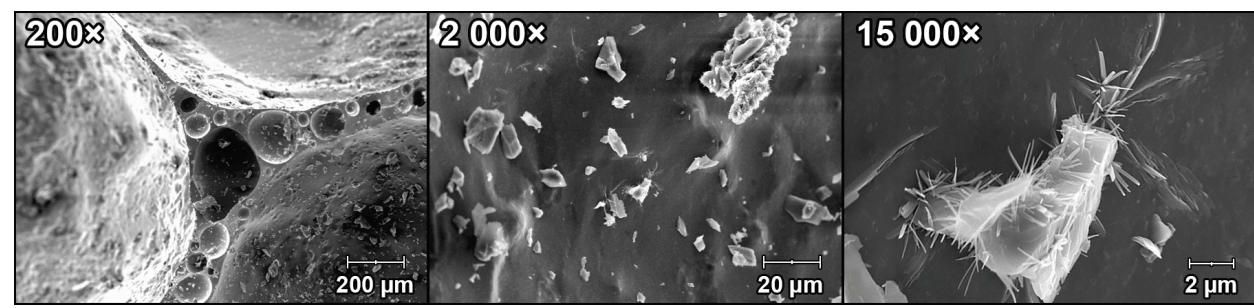

Obr. 6 Mikrofotografie vnitřní části póru pěnového skla ze SEM. 


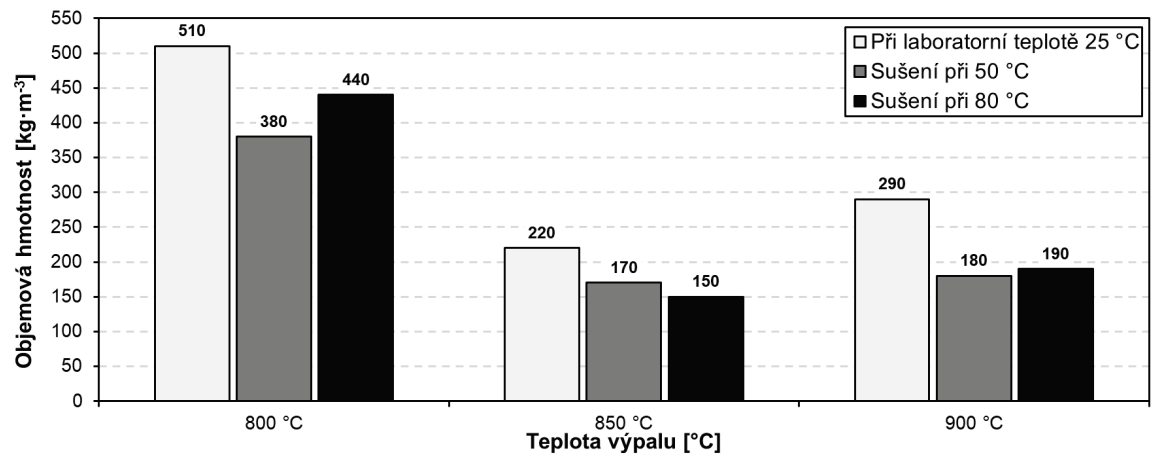

Obr. 7 Objemová hmotnost pěnových skel po výpalu na tři různé teploty.

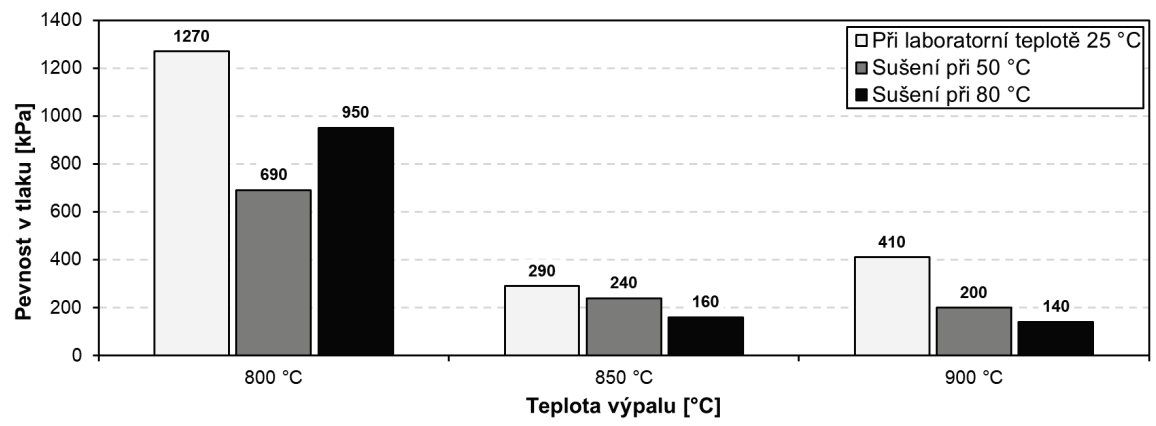

Obr. 8 Pevnost v tlaku pěnových skel po výpalu na tři různé teploty.

\section{DISKUZE}

Výsledky chemického složení odpadní křemeliny použité jako vstupní suroviny se nacházejí v Tab. 1. Výsledky mineralogického složení odpadní křemeliny se nacházejí na Obr. 1 a následné kvantitativní zastoupení minerálů a amorfní fáze poté v Tab. 2. Majoritní krystalickou fází je kaolinit a minoritními krystalickými fázemi křemen, anatas, kalcit. Majoritní obsah kaolinitu v odpadní křemelině je dán tím, že se jedná o vedlejší surovinu z těžby křemeliny a jejím třídění pomocí odstředivkových třídičů. Obsah amorfní fáze v odpadní křemelině je 39,16\%. Fotografie odpadní křemeliny z rastrovacího elektronového mikroskopu se nacházejí na Obr. 2. Vlevo lze spatřit shluky kaolinitu a vpravo schránky rozsivek.

Na Obr. 3 se nacházejí fotografie tablet pěnového skla vypálených na teploty $800{ }^{\circ} \mathrm{C}, 850{ }^{\circ} \mathrm{C}$ a $900{ }^{\circ} \mathrm{C}$. $\mathrm{Z}$ hlediska pórovitosti se jako nejoptimálnější jeví směs vypálená přri $850^{\circ} \mathrm{C}$. Výsledky rentgenové difrakční analýzy pěnového skla vypáleného na tři různé teploty výpalu se nachází na Obr. 4. Jedinou krystalickou fází ve všech směsích je nefelín $\mathrm{Na}_{3} \mathrm{KAl}_{4} \mathrm{Si}_{4} \mathrm{O}_{16}$. Na Obr. 5 a 6 se nacházejí mikrofotografie z rastrovacího elektronového mikroskopu pěnových skel. Na Obr. 5 se nachází sada 3 snímků vnějšího povrchu pěnového skla při zvětšení zleva $200 \times, 2000 \times$ a $15000 \times$. Na Obr. 6 se poté nachází sada 3 snímků vnitřní části póru pěnového skla př̀i stejných zvětšeních.

Obr. 7 znázorňuje porovnání objemových hmotností pěnových skel připravených při laboratorní teplotě, sušením při $50^{\circ} \mathrm{C} \mathrm{a} 80^{\circ} \mathrm{C}$ a třech různých teplotách výpalu $800^{\circ} \mathrm{C}, 850{ }^{\circ} \mathrm{C}$ a $900{ }^{\circ} \mathrm{C}$. Pěnová skla vypálena při $800{ }^{\circ} \mathrm{C}$ dosahovala nejvyšších hodnot objemových hmotností, ale na úkor porozity. Pěnová skla vypálena při $850^{\circ} \mathrm{C}$ a $900{ }^{\circ} \mathrm{C}$ již měla optimální objemovou hmotnost a porozitu srovnatelnou s tepelnými izolacemi na bázi organických polymerů. Obr. 8 znázorňuje pevnost v tlaku pěnových skel. Nejvyšších hodnot dosahovala pěnová skla vypálena při $800^{\circ} \mathrm{C}$, což je dáno vyšší objemovou hmotností a porozitou těchto vzorků. Pevnost v tlaku pěnových skel vypálených při $850^{\circ} \mathrm{C}$ a $900^{\circ} \mathrm{C}$ je taktéž srovnatelná i vyšší než výrobky použivané jako tepelná izolace na bázi organických polymerů. 


\section{ZÁVĚR}

Cílem tohoto článku byla analýza odpadní křemeliny využité jako vstupní surovina pro výrobu pěnového skla. Odpadní křemelina obsahovala jako majoritní krystalickou fázi kaolinit v množství téměř 60 \% a amorfní fázi v množství $39 \%$. Analýza chemického složení to taktéž potvrdila. Anorganická pěnová skla byla vyrobena lisováním do tablet a vypálena pomocí práškové spékací metody na tři různé teploty výpalu $-800{ }^{\circ} \mathrm{C}, 850{ }^{\circ} \mathrm{C}$ a $900{ }^{\circ} \mathrm{C}$. Rentgenovou difrakční analýzou bylo zjištěno že všechna pěnová skla jsou tvořena jedinou krystalickou fází - nefelínem. Z výsledků stanovení objemové hmotnosti a pevnosti v tlaku bylo zjištěno, že nejvyšších hodnot dosahovala pěnová skla vypálena při $800^{\circ} \mathrm{C}$, avšak pro účely využití tohoto anorganického pěnového skla jako tepelné izolace jsou vhodnější hodnoty objemových hmotností a pevností pěnových skel vypálených při $850^{\circ} \mathrm{C}$ a $900^{\circ} \mathrm{C}$, jež jsou srovnatelné s výrobky tepelných izolací na bázi organických polymerů.

\section{Poděkování}

Tento příspěvek byl podpořen v rámci řešení juniorského grantu mezifakultního specifického výzkumu pod interní grantovou agenturou Vysokého učení technického v Brně s číslem FAST/FCH-J-21-7280 a názvem: Využití odpadní křemeliny jako sekundární suroviny pro výrobu moderních anorganických izolačních materiálů.

\section{Použité zdroje}

[1] HARWOOD, D. M., J. P. SMOL a E. F. STOERMER. Diatomite. The Diatoms. Cambridge: Cambridge University Press, 2010, 570-574. ISBN 9780511763175. doi:10.1017/CBO9780511763175.034

[2] Diatomite Processing. https://www3.epa.gov/ttn/chief/ap42/ch11/final/c11s22.pdf

[3] IVANOV, S. É. a A. V. BELYAKOV. Diatomite and its applications. Glass and Ceramics. 2008, 65(1-2), 48-51. ISSN 0361-7610. doi:10.1007/s10717-008-9005-6

[4] Surovinové zdroje České republiky - nerostné suroviny 2019. Dostupné z: http://www.geology.cz/extranet/publikace/online/surovinove-zdroje/surovinove-zdroje-ceskerepubliky-2019.pdf

[5] Diatomite [online]. Dostupné z: https://pubs.usgs.gov/periodicals/mcs2021/mcs2021-diatomite.pdf

[6] SCHEFFLER, M. a P. COLOMBO. Cellular Ceramics. Wiley-VCH Verlag GmbH \& Co., 2005. ISBN 978-3-527-31320-4

[7] MANEVICH, V. E. a K. Yu. SUBBOTIN. Foam glass and problems of energy conservation. Glass and Ceramics. 2008, 65(3-4), 105-108. ISSN 0361-7610. doi:10.1007/s10717-008-9026-1

[8] Foam Glass Market by Type (open cell and Closed Cell), Process (Physical and Chemical), Application (Building \& Industrial Insulation and Chemical Processing Systems), End-Use Industry (Building \& Construction and Industrial) - Global Forecast to 2024. Dostupné z: https://www.marketsandmarkets.com/Market-Reports/foam-glass-market-3506071.html

[9] KARANDASHOVA, N S, B M GOLTSMAN a E A YATSENKO. Analysis of Influence of Foaming Mixture Components on Structure and Properties of Foam Glass. IOP Conference Series: Materials Science and Engineering. 2017, 262. ISSN 1757-8981. doi:10.1088/1757-899X/262/1/012020

[10] KHAMIDULINA, D D, S A NEKRASOVA a K M VORONIN. Foam Glass Production from Waste Glass by Compression. IOP Conference Series: Materials Science and Engineering. 2017, 262. ISSN 1757-8981. Dostupné z: doi:10.1088/1757-899X/262/1/012008

[11] BAI, Jianguang, Xinghua YANG, Shaochun XU, Wenjia JING a Jianfeng YANG. Preparation of foam glass from waste glass and fly ash. Materials Letters. 2014, 136, 52-54. ISSN 0167577X. Dostupné z: doi:10.1016/j.matlet.2014.07.028

[12] CHAKARTNARODOM, Parinya, Pitcharat INEURE, Shaochun XU, Wenjia JING a Jianfeng YANG. Foam Glass Development Using Glass Cullet and Fly Ash or Rice Husk Ash as the Raw Materials. Key Eng. Mat. 2014, 608, 73-78. ISSN 1662-9795. doi:10.4028/www.scientific.net/KEM.608.73

[13] YE, Zhong Nan, Yong Wei WANG, Hao JIANG, Na LI a Shi Quan LIU. Foamed Glass-Ceramics Made from Red-Mud. Key Engineering Materials. 2013, 575-576, 461-464. ISSN 1662-9795. Dostupné z: doi:10.4028/www.scientific.net/KEM.575-576.461

[14] YATSENKO, Elena A., B.M. GOLTSMAN a A.V. RYABOVA. Complex Protection of Pipelines Using Silicate Materials Based on Local Raw Materials of the Far East. In: Materials Science Forum. 2019, s. 46-52. ISSN 1662-9752. Dostupné z: doi:10.4028/www.scientific.net/MSF.945.46

[15] YATSENKO, Elena A., Boris M. GOLTSMAN, Lyudmila V. KLIMOVA a Lyubov A. YATSENKO. Peculiarities of foam glass synthesis from natural silica-containing raw materials. Journal of Thermal Analysis and Calorimetry. 2020, s. 119-127. ISSN 1388-6150. doi:10.1007/s10973-020-10015-3 